\title{
When salt is needed to grow: Questions
}

\section{Ester Conversano $^{1} \cdot$ Sara Romano $^{1} \cdot$ Andrea Taddio $^{1,2} \cdot$ Flavio Faletra $^{3} \cdot$ Davide Zanon $^{4} \cdot$ Egidio Barbi $^{1,2}$. Marco Pennesi ${ }^{2}$}

Received: 28 May 2020 / Accepted: 2 June 2020 / Published online: 10 August 2020

(C) The Author(s) 2020

Keywords Child $\cdot$ Metabolic acidosis $\cdot$ Hyperkalaemia $\cdot$ Hyponatraemia $\cdot$ Failure to thrive

\section{Case summary}

A 50-day-old girl was referred for a history of recurrent vomiting, poor feeding and moderate failure to thrive. She was born by a caesarean section at $41+5$ weeks of gestation, from nonconsanguineous parents. Her birth weight was $3430 \mathrm{~g}$ and she was fed with breast milk and formula. Upon admission, her weight was $3700 \mathrm{~g} \mathrm{(} 3^{\circ}$ percentile) and blood pressure was normal. Physical examination showed mild dystrophy with poor representation of subcutaneous fat, normal external genitalia and age-appropriate psychomotor development.

Laboratory tests showed mild hyponatraemia $(130 \mathrm{mEq} / \mathrm{L})$ and hyperkalaemia $(6 \mathrm{mEq} / \mathrm{L})$, normal plasma creatinine $(0.26$ $\mathrm{mg} / \mathrm{dl}$ ) and metabolic acidosis (pH 7.23, pCO2 $53 \mathrm{mmHg}$, $\mathrm{HCO}^{-} 21.8 \mathrm{mmol} / \mathrm{L}$, lactic acid $7.5 \mathrm{mmol} / \mathrm{L}$ ). Potassium and sodium urinary fractional excretion were $23 \%$ and $0.98 \%$, respectively. In the urine sample, no proteinuria, white blood cells, bacteria or haematuria were detected. Abdominal ultrasound results were normal.

Due to the acidosis with persistence of poor feeding and vomiting, a hydration with an intravenous physiological solution was empirically started. While metabolic acidosis was

The answers to these questions can be found at https://doi.org/10.1007/ s00467-020-04647-8.

Sara Romano

sara.romano17@gmail.com

1 Department of Medicine, Surgery, and Health Sciences, University of Trieste, Trieste, Italy

2 Paediatric Department, Institute for Maternal and Child Health IRCCS "Burlo Garofolo", Trieste, Italy

3 Genetic Department, Institute for Maternal and Child Health - IRCCS "Burlo Garofolo", Trieste, Italy

4 Pharmacy and Clinical Pharmacology Department, Institute for Maternal and Child Health - IRCCS "Burlo Garofolo", Trieste, Italy resolved with the infusion, hyponatraemia and hyperkalaemia persisted. Further analysis revealed a significant increase of plasma renin activity and aldosterone (respectively, $>500$ $\mu \mathrm{UI} / \mathrm{mL}$, normal value $444 ;>1000 \mathrm{ng} / \mathrm{dL}$, normal value $30-50)$.

\section{Questions}

1. What is the most likely diagnosis?

2. What would be an alternative diagnosis?

3. What is the treatment and prognosis of the disease?

Acknowledgements The authors thank Giulia Pennesi, Edinburgh Napier University, Edinburgh, United Kingdom, for the English revision of the manuscript.

Funding Information Open access funding provided by Università degli Studi di Trieste within the CRUI-CARE Agreement.

\section{Compliance with ethical standards}

Conflict of interest The authors declare that they have no conflict of interest.

Open Access This article is licensed under a Creative Commons Attribution 4.0 International License, which permits use, sharing, adaptation, distribution and reproduction in any medium or format, as long as you give appropriate credit to the original author(s) and the source, provide a link to the Creative Commons licence, and indicate if changes were made. The images or other third party material in this article are included in the article's Creative Commons licence, unless indicated otherwise in a credit line to the material. If material is not included in the article's Creative Commons licence and your intended use is not permitted by statutory regulation or exceeds the permitted use, you will need to obtain permission directly from the copyright holder. To view a copy of this licence, visit http://creativecommons.org/licenses/by/4.0/.

Publisher's note Springer Nature remains neutral with regard to jurisdictional claims in published maps and institutional affiliations. 